\title{
LAND USE/LAND COVER CHANGES ANALYSIS IN SUDANO GUINEAN REGION OF BENIN
}

\author{
AYENIKAFO, O. M. ${ }^{1}-$ WANG, Y. F..$^{1,2^{*}}$ \\ ${ }^{1}$ College of economics and management, Northeast Forestry University, Harbin 150040, China \\ ${ }^{2}$ Business School of Shanghai Dianji University, Shanghai, China \\ *Corresponding author \\ e-mail:wyfbhs@sina.com; phone: +86-133-9115-0016
}

(Received $10^{\text {th }}$ Oct 2020; accepted 21 $1^{\text {st }}$ Dec 2020)

\begin{abstract}
Deforestation processes driven by anthropogenic activities lead to the loss of biodiversity and the alteration of ecological systems. In this paper, we examined the land use / land cover change trends from 2000 to 2020 in the Sudano-Guinean region of Benin, and analysed the driving factors of those changes. The adopted method is based on the diachronic analysis of the land cover through the use of remote sensing data specifically, Landsat satellite images of 2000 and 2020. The results showed that natural forest vegetation and Savannah strongly decreased, whereas farmland and the built-up area increased. Indeed, forest land lost $3.22 \%, 2.01 \%$, and $1.57 \%$, in Bante, Glazoué, and Ouèssè, respectively. The intensification of human activities was identified as the proximate driver while population growth, a growing demand for agricultural and forest products coupled with improved infrastructure were identified as the underlying drivers of deforestation. To achieve sustainable management goal for forest resources in Benin, the introduction of alternative sources of energy, sustainable farming practices, diversification of income sources, the promotion of community participation, should be implemented.
\end{abstract}

Keywords: Benin, Sudano-Guinean zone, land use/land cover change, forest change, remote sensing

\section{Introduction}

Land use / land cover change (LULC) is one of the main causes of terrestrial surface alteration, therefore discussions on sustainable development should take this into account. LULC change is regarded as all change observed in the natural landscape of Earth (Lambin and Meyfroidt, 2010), leading not only to loss of biodiversity, but also to climate change (Verburg et al., 2009; Hibbard et al., 2010; Lambin and Meyfroidt, 2011; Meyfroidt et al., 2013; Van Asselen and Verburg, 2013). According to Turner and Billie (2001), numerous human activities constitute the main causes that have recently been influencing the biosphere in several ways. Indeed, it was highlighted that LULC change is regarded as the major indicator of Earth's terrestrial surface alteration inducted by human populations. Therefore, land use is considered to be a major driver (Foley et al., 2005) due to anthropogenic activities such as agriculture, pasture, and urbanization for their negative impact on the environment. Schaldach et al. (2006) has stated that these change will in the future cause an increase demand of food and energy for the world population. Recently, numerous studies have widely integrated remote sensing (RS) and geographic information system (GIS) in the field of land use land cover change for the purpose of management of land and other natural resources. Thus, studies on monitoring and assessing LULC changes are crucial to agriculturalists, urban planners, policy maker, environmentalists and scientists (Babalola and Akinsanola, 2016). In addition, Remote sensing technologies provide the acquisition of LULC information over large areas at no cost from local to global scales (Mishra and Rai, 2016). Therefore, the integration of remote sensing and GIS approaches is regarded as the best method for extracting and 
assessing the change trends of LULC changes (Kumar and Shaikh, 2013; Mishra and Rai, 2016; Mishra et al., 2018). Thapa and Murayama (2010) have stated that transition from rural to urban landscape is possible due to the population migration from village to town and city. According to Moghadam and Helbich (2013) and Li et al. (2013), the projection by 2050 indicates that around $72 \%$ of the world's population will reside in cities. This large concentration of human population in cities is not without consequences. Thapa and Murayama (2010) confirmed that the urban growth consequence on land use changes is a complex interaction between behaviour and structural factors with the demand, the technological capacity which at the end strains the environment. Socioeconomic pressures (forest patterns, agricultural, migration and urban sprawl) strongly contribute to urban growth (Thapa and Murayama, 2009). Thus, the land is used for goods and services production and as residential land for those migrating from the village to the city ( $\mathrm{Lu}$ and Sasaki, 2008). The key for better understanding the interactions between anthropogenic activities and the environment is in performing studies on land use land cover change (Dewan et al., 2012). Lambin et al. (2001) have stated that human activities all round modification in land use/cover recently has become as the one extremely influencing our ecological systems. Thus, the change of land use and cover caused by the intensive socio-economic development lead to environmental degradation (Grimm et al., 2008). Additionally, change in forest landscape due to human activities lead to greenhouse gas increasing in the atmosphere which resulting in climate change (Dewan et al., 2012). In the last two decades, Benin Republic faced rapid population growth and urban expansion. Whereof, acquiring accurate information in the past land cover are very important for the purpose of land use planning and sustainable management. From 2000 to 2015 , the population of Benin increased by around 54\% from 6.7 million to 10.6 million (United Nations, 2017). From 2000 to 2015, the population density increased from around 61 inhabitants $/ \mathrm{km}^{2}$ to 94 inhabitants $/ \mathrm{km}^{2}$ (INSAE_Benin, 2014). This has led to great loss of forest cover in the country, with an average annual deforestation rate of 1.95\%. From 1990 to 2005, Benin has lost 29.2\% (971000 ha) of its forest cover (Thomson, 2007). Most of populations, especially rural populations, mainly depend on forest products to survive (Schumann et al., 2012). Recently, numerous research has been performed in the field of land use land cover change by integrating remote sensing and GIS technologies (Srivastava et al., 2013; Houessou et al., 2013; Oladoye et al., 2014; Mishra and Rai, 2016; Babalola and Akinsanola, 2016; Issiaka et al., 2016; Mishra et al., 2018). Nonetheless, studies on LULC change in Benin Republic was very limited in some regions. The present study aimed to assess the forest cover change in the Sudano-Guinean region of Benin, one of the region with high population density and pressure on forest resources, for the purpose of providing accurate information for sustainable development and management of forest land.

\section{Materials and Methods}

\section{Study Area}

The study area is located in Benin, between $8^{\circ}$ and $9^{\circ}$ north latitude and between $2^{\circ}$ 10 and $2^{\circ} 49$ east longitude. It covers an area of approximately 7,445 square kilometers (Figure 1). Governed by a tropical transition climate (Afouda, 1990), this area is characterized by annual average rainfall and temperature of $1,300 \mathrm{~mm}$ and $27{ }^{\circ} \mathrm{C}$, respectively. The relief is a crystalline peneplain marked by the presence of inselbergs with an altitude ranging from 200 to $400 \mathrm{~m}$ (Adam and Boko, 1993). The soils belong to 
the sizeable ferruginous ensemble of the tropical environment (Igue, 2000). Agriculture is extensive, characterized by low crop yields. Logging and climate instability have increased in recent years (Oloukoi et al., 2006).

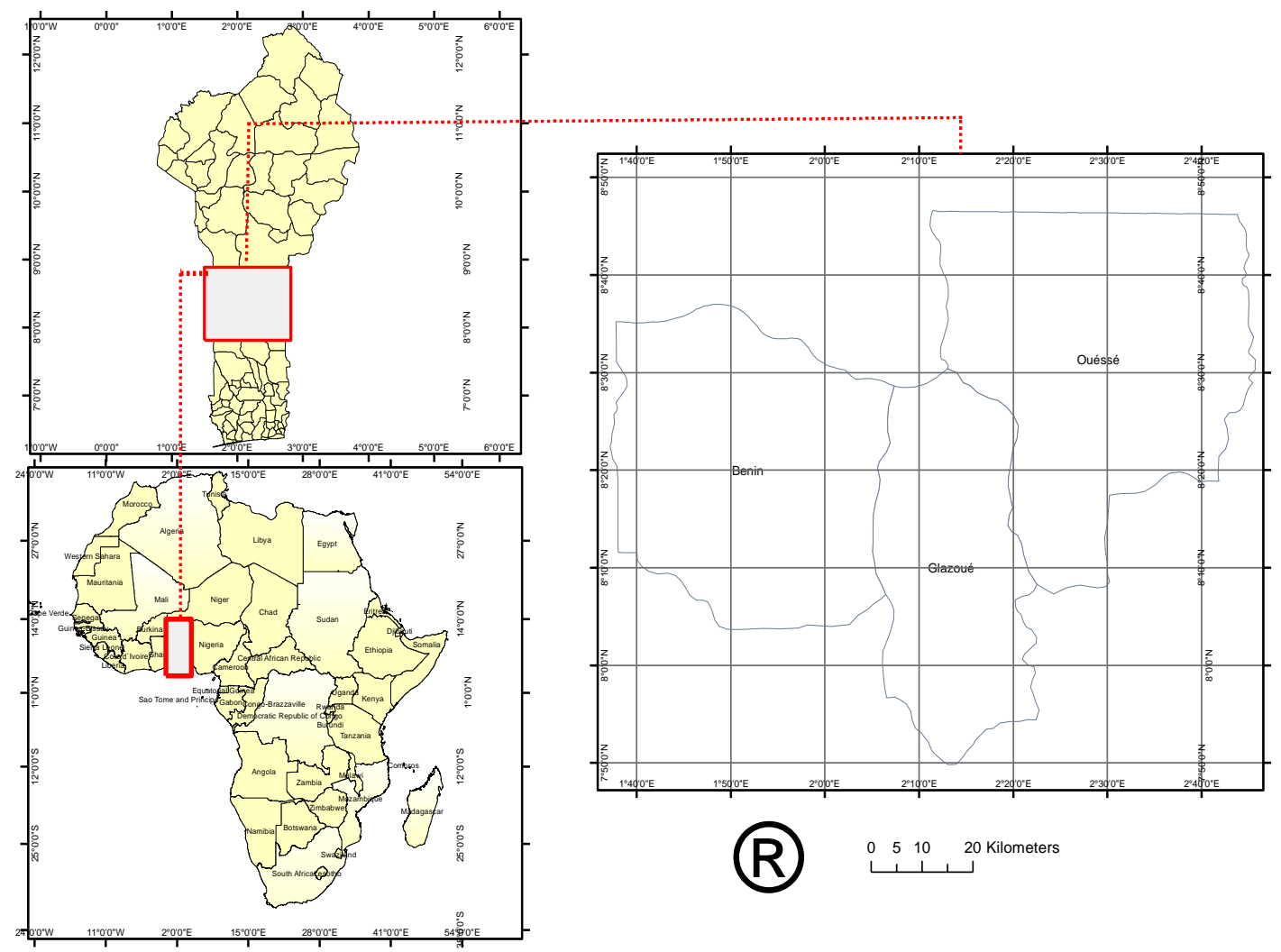

Figure 1. Location of the study area

\section{Data collection}

According to the Landsat Worldwide Reference System (WRS), our study area is located at the Path and Row position of 174 and 59, respectively. Thus, Landsat images of the year 2000 and 2020, were freely downloaded from the website of the US Geological Survey National Center for Earth Resources Observation and Science (http://glovis.usgs.gov/), in order to extract crucial information on land use/ land cover change in the study area. Also, as it requires to better know the region before performing supervised classification, field observations were carried out during March 2020 to understand the characteristics of each land use/ land cover category. Thus, for each land use/ land cover class, 150 training reference points were collected using the GPS receiver. The three Landsat images were acquired in March and February because of cloud-free images or clear sky during that period (Table 1). Indeed, using satellite images acquired almost in the same period remains an essential advantage of land use/land cover change study. This removes the effects of change in season when investigating year-to-year change and also minimizes the discrepancies in reflectance caused by seasonal vegetation fluxes, climatic differences, and sun angle differences (Singh, 1989). 
Table 1. Characteristics of remotely sensed data used for the study

\begin{tabular}{c|c|c|c|c|c}
\hline Sensors & $\begin{array}{c}\text { Acquisition } \\
\text { date }\end{array}$ & $\begin{array}{c}\text { Spatial } \\
\text { resolution }\end{array}$ & Path/row & $\begin{array}{c}\text { Band } \\
\text { combination }\end{array}$ & Source \\
\hline LT05 & March 2000 & $30 \mathrm{~m}$ & $174 / 59$ & $5,4,3$ & $\underline{\text { http://glovis.usgs.gov/. }}$ \\
LE07 & February 2020 & $30 \mathrm{~m}$ & $174 / 59$ & $5,4,3$ & $\underline{\text { http://glovis.usgs.gov/. }}$ \\
LC08 & March 2020 & $30 \mathrm{~m}$ & $174 / 59$ & $6,5,4$ & $\underline{\text { http://glovis.usgs.gov/. }}$ \\
\hline
\end{tabular}

\section{Land use/land cover classification}

As shown in Figure 2, after performing the image preprocessing (radiometric calibration and atmospheric correction using the FLAASH method), we then carried out a supervised classification of the 2000 and 2020 satellite images. Firstly, field data were collected for each land category in order to identify the spectral signature of each one. Also, using the maximum likelihood algorithm, satellite images were classified into four categories, namely forest, farmland, Savannah, and built-up area. The maximum likelihood algorithm is a parametric decision whose rule is based on the probability that has a specific pixel belonging to a specific category. It has been reported that this algorithm provides a higher classification accuracy in land use/land cover study (Vadrevu, 2013). For the calculation of the observed rates of change, the global rates of change (Tg) express the proportion of an occupancy unit that changes during a given period or between two dates. It was evaluated according to the formula used by Oloukoi (2006):

$$
\operatorname{Tg}=[(\mathrm{S} 2-\mathrm{S} 1 / \mathrm{S} 1)]^{*} 100
$$

where $\mathrm{S} 1$ and $\mathrm{S} 2$ are the area at $\mathrm{t} 1$ and $\mathrm{t}+1$, respectively.

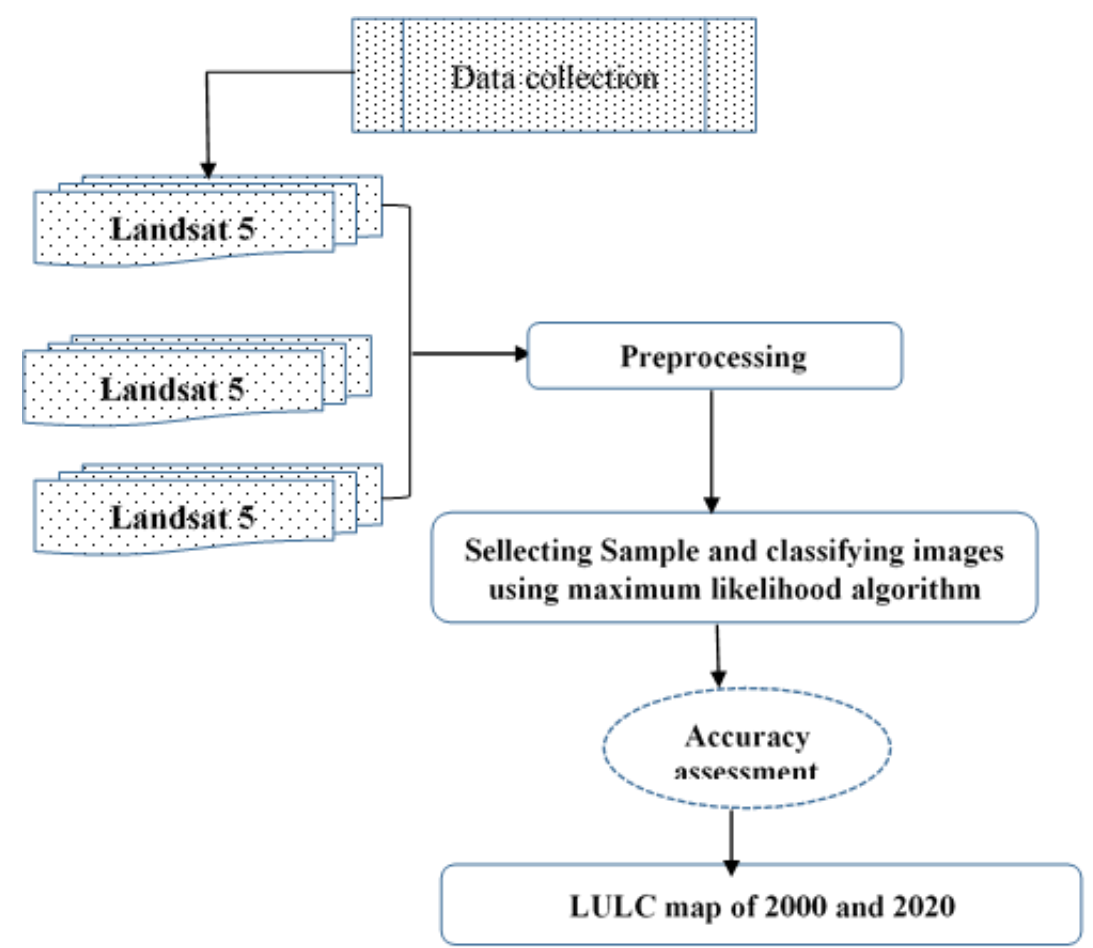

Figure 2. Schematic diagram of the research approach 
Analysis of the rate of change values shows that positive values indicate progression, and negative values indicate regression. Values close to zero indicate that the class is relatively stable (Kpédénou et al., 2017).

\section{Socioeconomic survey}

Socio-economic surveys were carried out among the main actors whose activities affect in one way or another, the forest land. These are mainly farmers, ranchers, loggers and charcoal makers. Since statistical data on the number of these different actors is not available, the size of the sample to be surveyed at the level of each category of actor was determined using the formula of Dagnelie (1998). In total, 100 actors were interviewed. Its formula is as follows:

$$
n=\frac{p(1-p) U U_{1 \frac{\alpha}{2}}^{2}}{d^{2}}
$$

where $\mathrm{p}$ being the proportion of each category of actors, obtained from an exploratory survey, $\mathrm{d}=10 \%$ (margin of error varying from 0 to $20 \%$ ).

\section{Results}

\section{Evolution in a forest area during the last two decades}

During our survey, the landscape of our study area was classified into four categories, including forest, farmland, wooded land, and bare land, in Bante, Glazoué, and Ouèssè. The total area for each year in the area under study reveals that the greater part of the change has been occurred in forest conversion to other land categories. Based on analysis performed from 2000 to 2020 in Bante (Table 2), it was noted that one category experienced negative change while three others experienced positive change. Indeed, Builtup land had the highest positive change rate (12.54\%), followed by Farm and Savannah with $12.36 \%$ and $6.64 \%$, respectively. On the other hand, Forest land experienced the highest negative change rate $(-3.22 \%)$. During the period from 2000 to 2020, Forest land lost 6,563.65 ha each year, in favor of Farmland, Builtup land, and Savannah. In Glazoué, the landscape has been changed in different ways compared to Bante (Table 3). It was noted that two categories of the landscape experienced a negative change, and two others experienced a positive change. Farmland had the highest positive change rate $(7.83 \%$ ), followed by Builtup land with 5.79\%, while Savannah and forest land lost $0.97 \%$ and $2.01 \%$, respectively. From 2000 to 2020, 1091.2 ha of forests and 930.65 ha of Savannah disappeared in favor of farmland and Builtup area, each year. In Ouèssè, the landscape dynamics has been occurred in the same way as in Glazoué (Table 4). However, the statistics of change were different, it was noted that two categories of the landscape experienced a negative change, and two others experienced a positive change. Indeed, farmland had the highest positive change rate $(6.69 \%)$ followed by the Builtup area with 5.49\%. In comparison, forest and Savannah lost $1.57 \%$ and $0.46 \%$, respectively. On the other hand, forests experienced the highest negative change rate and lost each year 2,882.55 ha, while wooded land lost 344.65 ha. 
Table 2. Evolution of land use/cover in Bantè, from 2000 to 2020

\begin{tabular}{c|c|c|c|c|c|c}
\hline \multirow{2}{*}{$\begin{array}{c}\text { Land use/cover } \\
\text { classes }\end{array}$} & \multicolumn{3}{c|}{ Spatial area coverage } & \multicolumn{2}{c}{$\begin{array}{c}\text { The annual rate of } \\
\text { change }\end{array}$} \\
\cline { 2 - 7 } & \multicolumn{2}{|c|}{2000} & \multicolumn{2}{c}{2020} & \multicolumn{2}{c}{$2000-2020$} \\
\cline { 2 - 7 } & Area(ha) & $\%$ & Area(ha) & $\%$ & ha/year & $\% /$ year \\
\hline Forest & 203936 & 77.25 & 72663 & 27.53 & $-6563,65$ & -3.22 \\
Farmland & 44407 & 16.82 & 154150 & 58.39 & 5487,15 & 12,36 \\
Savannah & 15005 & 5.68 & 34937 & 13.23 & 996,60 & 6.64 \\
Bare land & 637 & 0.24 & 2235 & 0.85 & 79,90 & 12.54 \\
\hline Total & 263985 & 100 & 263985 & 100 & & \\
\hline
\end{tabular}

Table 3. Evolution of land use/cover in Glazoué from 2000 to 2020

\begin{tabular}{c|c|c|c|c|c|c}
\hline \multirow{2}{*}{$\begin{array}{c}\text { Land use/cover } \\
\text { classes }\end{array}$} & \multicolumn{3}{c|}{ Spatial area coverage } & \multicolumn{2}{c}{$\begin{array}{c}\text { The annual rate of } \\
\text { change }\end{array}$} \\
\cline { 2 - 7 } & \multicolumn{2}{|c|}{2000} & \multicolumn{2}{c}{2020} & \multicolumn{2}{c}{$2000-2020$} \\
\cline { 2 - 7 } & Area(ha) & $\%$ & Area(ha) & $\%$ & ha/year & $\% /$ year \\
\hline Forest & 54282 & 30.89 & 32458 & 18.47 & $-1091,20$ & -2.01 \\
Farmland & 25500 & 14.51 & 65412 & 37.23 & 1995,60 & 7.83 \\
Savannah & 95476 & 54.34 & 76863 & 43.74 & $-930,65$ & -0.97 \\
Bare land & 453 & 0.26 & 978 & 0.56 & 26,25 & 5.79 \\
\hline Total & 175711 & 100 & 175711 & 100 & & \\
\hline
\end{tabular}

Table 4. Evolution of land use/cover in Ouèssè from 2000 to 2020

\begin{tabular}{c|c|c|c|c|c|c}
\hline \multirow{2}{*}{$\begin{array}{c}\text { Land use/cover } \\
\text { classes }\end{array}$} & \multicolumn{3}{c|}{ Spatial area coverage } & \multicolumn{2}{c}{$\begin{array}{c}\text { The annual rate of } \\
\text { change }\end{array}$} \\
\cline { 2 - 7 } & \multicolumn{2}{|c|}{2000} & \multicolumn{2}{c}{2020} & \multicolumn{2}{c}{$2000-2020$} \\
\cline { 2 - 7 } & Area(ha) & $\%$ & Area(ha) & $\%$ & ha/year & $\% /$ year \\
\hline Forest & 183025 & 59.60 & 125374 & 40.83 & $-2882,55$ & -1.57 \\
Farmland & 47523 & 15.47 & 111084 & 36.17 & 3178,05 & 6.69 \\
Savannah & 75652 & 24.63 & 68759 & 22.39 & $-344,65$ & -0.46 \\
Bare land & 896 & 0.29 & 1879 & 0.61 & 49,15 & 5.49 \\
\hline Total & 307096 & 100 & 307096 & 100 & & \\
\hline
\end{tabular}

\section{Proximate drivers of deforestation}

Analysis of Table 5 reveals that agriculture, fuelwood collection, pasture and Forest fire are the main drivers of deforestation in the study area. For pastoralists and charcoal makers, the most important drivers of deforestation are agriculture and fuelwood collection. For farmers and loggers, it is above all agriculture and fuelwood collection that lead to significant deforestation too. On the other hand, hunters point out agriculture and fuel wood collection as the main drivers of deforestation. 
Table 5. Variation in the score of the direct factors of deforestation according to the categories of actors

\begin{tabular}{c|c|c|c|c|c}
\hline \multirow{2}{*}{ Drivers } & \multicolumn{5}{|c}{ Actors } \\
\cline { 2 - 6 } & $\begin{array}{c}\text { Farmers } \\
(\mathrm{n}=35)\end{array}$ & $\begin{array}{c}\text { Breeders } \\
(\mathrm{n}=15)\end{array}$ & $\begin{array}{c}\text { Loggers } \\
(\mathrm{n}=20)\end{array}$ & $\begin{array}{c}\text { Charcoal } \\
\text { makers }(\mathrm{n}=15)\end{array}$ & $\begin{array}{c}\text { Hunters } \\
(\mathrm{n}=15)\end{array}$ \\
\hline Agriculture & 85 & 80 & 83 & 89 & 90 \\
Fuel Wood collection & 10 & 15 & 8 & 8 & 5 \\
Pasture & 12 & 3 & 5 & 2 & 3 \\
Forest fire & 3 & 2 & 4 & 1 & 2 \\
\hline
\end{tabular}
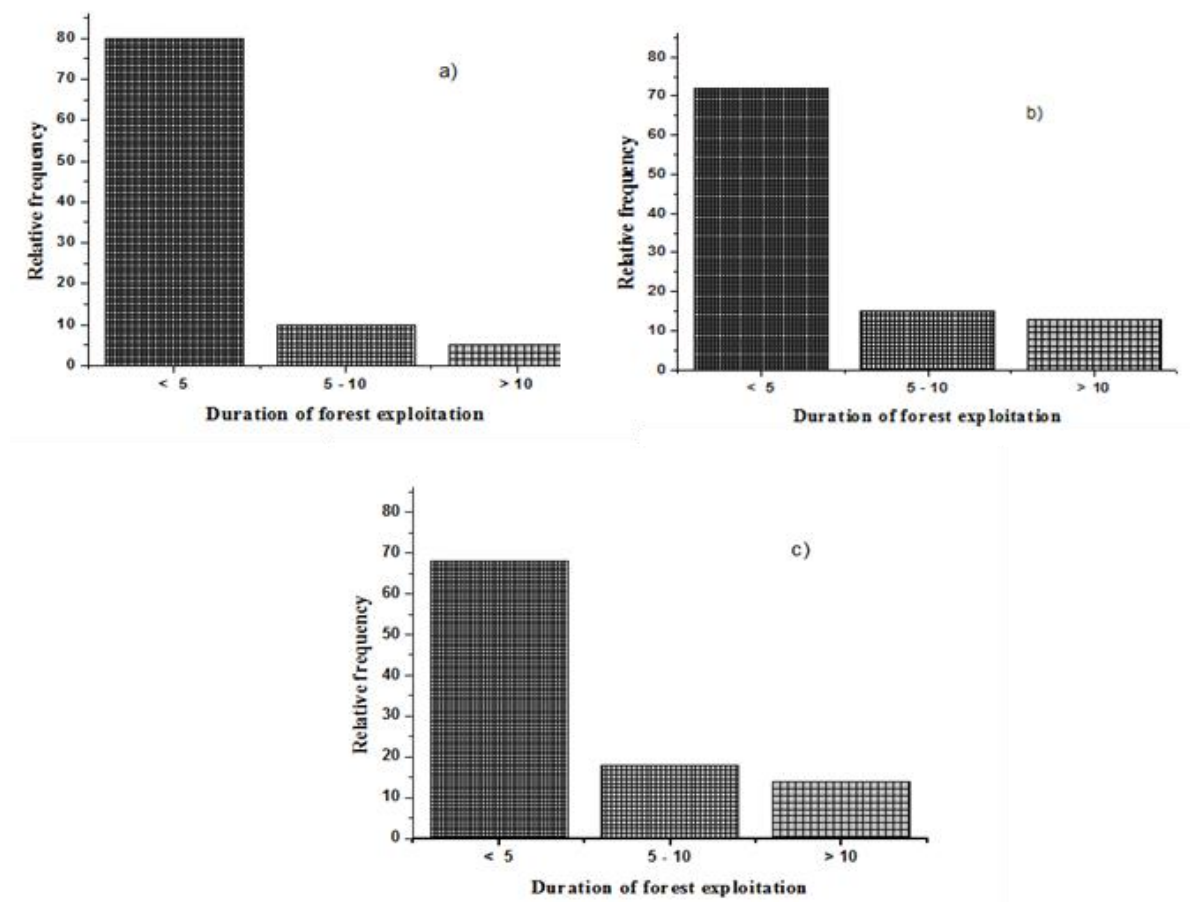

Figure 3. Duration of exploitation of forest lands in the city of a) Banté, b) Glazoué and c) Ouèssè

\section{Discussion}

During the last two decades, the rapid population increase has been led to major change in the landscape of the Sudano-Guinean region of Benin. Thus, we conducted the present research for the purpose to analyse the land use / land cover change and its drivers. The results reveal a regression of forest lands in favor of farm lands and Builtup area, from 2000 to 2020. This suggests an increasing demand for cultivation lands by the local population and also lands for implementing new agglomerations. Indeed, from 2000 to 2020, forest lands have lost 3.22\%, 2.01\% and 1.57\% in Banté, Glazoué and Ouèssè, respectively. However, Farmland and Builtup area experienced positive change during the same period. Our results are consistent with those found by Mama et al. (2013) in the northern part of Benin, Avakoudjo et al. (2014) and Ousséni et al. (2016), during the period from 1986 to 2016. These studies have shown a continuous regression of forests in favor of farm lands and Builtup area. Indeed, deforestation results from the interaction of a set of socio-economic, political and institutional factors. According to the literature, these factors are categorized into proximate and underlying causes, and they have been 
extensively described by several authors, notably Lambin et al. (1999), Ojima, Galvin and Turner (1994), and Meyer and Turner (1992). Geist and Lambin (2002) define proximate causes as human actions that directly affect the environment, and can be illustrated by agricultural expansion, infrastructure expansion and timber extraction (Lambin, 1994; Kaimowitz and Angelsen, 1998; Arima et al., 2005; Caldas et al., 2007; Pacheco and Poccard-Chapuis, 2012). However, the underlying causes are the indirect causes that can be considered as the socio-economic, political, technological and demographic forces that underlie the immediate causes (Kaimowitz and Angelsen, 1998; Geist and Lambin, 2002). Therefore, according to Geist and Lambin (2002), deforestation can be explained as a result of the interaction of several factors rather than a single cause. Indeed, it results from a combination of factors working together. For example, economic factors can influence land use decision making by changing input prices. These price changes can lead to land conversion. For example, deforestation can result in a decrease in input prices. Similarly, policies and demographic factors influence deforestation. In fact, policies that favor farmers' access to credit or the market can accelerate the conversion of forests to cropland. In addition, the increase or decrease in population impacts land use. Carr (2009) has reported that migration is one of the most important demographic factors that affect land cover change. Thus, taking into account the availability of data in the study area, four causes of deforestation were analysed. Three of which are underlying causes and one is immediate cause. The underlying causes analysed are demographic changes, infrastructure development and market factors. The immediate cause is related to the expansion of agriculture. Generally, numerous studies in Benin have reported that agriculture is the main driver of deforestation (Mama et al., 2013; Avakoudjo et al., 2014; Ousséni et al., 2016; Ngo Makak et al., 2018). Indeed, in our study area, rapid expansion of perennial and annual crop in the 2000s seems to have happened simultaneously with the region's landscape change. The Landsat data classification reveals that forest lands decreased from 2000 to 2020 at the same time that introduced intensification of crop started as a result of market factors. Indeed, the results revealed that market-related factors (e.g., demand for maize, manioc, yamn, rice, cotton) should be one of the driving forces influencing forest land decrease. Generally, all perennial and annual crops increased in cultivated areas from 2000 to 2020 (Table 6). In conclusion, the most important annual crops are increasing in surface area at an increasing rate, resulting in decreasing in forest areas.

Table 6. Annual and perennial cultivated area by region

\begin{tabular}{c|c|c|c|c}
\hline & \multicolumn{2}{|c|}{ Annual crop } & \multicolumn{2}{c}{ Perennial crop } \\
\hline Year & 2000 & 2020 & 2000 & 2020 \\
\hline Banté & 31867 & 89305 & 32540 & 98845 \\
Ouèssè & 38125 & 89657 & 45658 & 87124 \\
Glazoué & 23758 & 58235 & 21428 & 45712 \\
Total & 93750 & 237197 & 99626 & 231681 \\
\hline
\end{tabular}

Although agriculture and cotton cultivation are reputedly main proximate causes of landscape change, it is crucial to point out here that several research on landscape change have also revealed strong correlation between population and road network in leading to these changes (Allen and Barnes, 1985; Kaimowitz and Angelsen, 1998; Mather and Needle, 2000; Carr, 2004; Pfaff et al., 2007). Although, correlation analysis between 
population, roads, and deforestation in the study area has not been done in this study, it is essential to make some comments. From 2002 to 2018, the population in the study area increased from 269454 to 431340 people - an increase of $60.1 \%$ (Table 7). For Hountondji (2008), the increasing rate of population growth in the study area still contributing to the forest land losses due to the increase in the demand of natural resources. Thus, population growth reputedly should also be one of the driving forces of deforestation in the region. Also, the renovation of the main roads linking Banté, Ouéssé and Gazoue to the capital city Cotonou, and the appearance of secondary routes seem to be contributing to the deforestation in the region. However, the most challenging aspect for landholders in the Chaco region is the lack of infrastructure, such as paved roads.

Table 7. Total population in the study area

\begin{tabular}{c|c|c|c|c}
\hline \multicolumn{5}{c}{ Years } \\
\hline Year & 2002 & 2013 & 2018 & $\begin{array}{c}\% \text { change } \\
(2002-2018)\end{array}$ \\
\hline Banté & 82129 & 107181 & 123739 & 50.7 \\
Ouèssè & 96850 & 142017 & 163956 & 69.3 \\
Glazoué & 90475 & 124431 & 143645 & 58.8 \\
Total & 269454 & 373629 & 431340 & 60.1 \\
\hline
\end{tabular}

\section{Conclusion}

This study highlights the relevance of the cartographic approach from satellite images. It thus contributes to the interpretation of landscape dynamics in the Sudano-Guinean zone of Benin. It reveals that the current human pressures on the forest resources are in rupture with the capacities of regeneration of the natural plant formations, which are thus seriously threatened. Also, a rapid extension of areas with agricultural influence is observed to the detriment of densely wooded formations. This global movement, starting from urban centers and rural hamlets, associated with an intensification of human activities, questions the sustainability of ecological, economic, and social processes in an area strongly dependent on climatic conditions. It, therefore, seems urgent to develop an integrated and participative management strategy both at the local and regional levels in order to conserve natural resources sustainably. The principles of this management must be based on the concerted development, between local decision-makers and populations, of development plans taking into account the clear definition of agricultural areas, the protection of natural areas as well as the control of ecological flows and processes whose areas are the subject. Therefore, it would be better for further studies, to examine the effects of climate change on land use/land cover change, and the effects of land use/land cover change on biodiversity composition.

\section{REFERENCES}

[1] Adam, S. K., Boko, M. (1993): Benin. - New edition. Cotonou, Benin, Editions of Flamboyant Edicef, 93p.

[2] Afouda, F. (1990): Water and crops in central and northern Benin: study of the variability of water budgets in their relations with the rural environment of the African savannah. Thesis, University of Paris IV (Sorbonne), France, 448p. 
[3] Allen, J. C., Barnes, D. F. (1985): The causes of deforestation in developing countries. Annals of the Association of American Geographers 75: 163-184.

[4] Arima, E. Y., Walker, R. T., Perz, S. G., Caldas, M. (2005): Loggers and forest fragmentation: Behavioral models of road building in the Amazon basin. - Annals of the Association of American Geographers 95: 525-541.

[5] Avakoudjo, J., Mama, A., Toko, I., Kindomihou, V., Sinsin, B. (2014): Dynamique de l'occupation du sol dans le Parc National du W et sa périphérie au nord-ouest du Bénin. International Journal of Biological and Chemical Sciences 8(6): 2608-2625.

[6] Babalola, O., Akinsanola, A. (2016): Change detection in land surface temperature and land use land cover over Lagos Metropolis, Nigeria. - J. Remote. Sens. GIS 5(3): 1-7.

[7] Caldas, M., Walker, R., Arima, E., Perz, S., Wood, C., Aldrich, S., Simmons, C. (2007): Theorizing land cover and land use change: The peasant economy of Amazonian deforestation. - Annals of the Association of American Geographers 97(1): 86-110.

[8] Carr, D. L. (2004): Proximate population factors and deforestation in tropical agricultural frontiers. - Population and Environment 25(6): 585-612.

[9] Carr, D. L. (2009): Population and deforestation: Why rural migration matters. - Progress in Human Geography 33(3): 355-378.

[10] Dagnelie, P. (1998): Statistique théorique et appliquée (Tome 2). - De Boeck \& Larcier, Paris-Bruxelles, 659p.

[11] Dewan, A. M., Yamaguchi, Y., Rahman, M. Z. (2012): Dynamics of land use/cover changes and the analysis of landscape fragmentation in Dhaka Metropolitan, Bangladesh. - Geo Journal 77(3): 315-330.

[12] EU (2017): Decree No. 331/2017 of 06 July 2017 defining the categorization of Protected Areas of the Republic of Benin according to the nomenclature of the World Union for the Conservation of Nature (UICN). - Official Journal of the European Union.

[13] Foley, J. A., DeFries, R., Asner, G. P., Barford, C., Bonan, G., Carpenter, S. R., Snyder, P. K. (2005): Global consequences of land use. - Science 309(5734): 570-574.

[14] Geist, H. J., Lambin, E. F. (2002): Proximate causes and underlying driving forces of tropical deforestation. - Bioscience 52(2): 143-150.

[15] Grimm, N. B., Faeth, S. H., Golubiewski, N. E., Redman, C. L., Wu, J., Bai, X., Briggs, J. M. (2008): Global change and the ecology of cities. - Science 319(5864): 756-760.

[16] Guy, C., Jacques, L. B., Martin, T. (2005): The plural forest: a new way of managing and using the forest, the case of the Forêt de l'Aigle. - Vertigo: 4298.

[17] Hibbard, K., Janetos, A., Van Vuuren, D. P., Pongratz, J., Rose, S. K., Betts, R., Feddema, J. J. (2010): Research priorities in land use and land-cover change for the Earth system and integrated assessment modelling. - Int J Climatol 30(13): 2118-2128.

[18] Houessou, L. G., Teka, O., Toko, I., Lykke, A. M., Sinsin, B. (2013): Land use and landcover change at "W" biosphere reserve and its surroundings areas in Benin Republic (West Africa). - Environ Nat Resour Res. 3(2).

[19] Hountondji, Y. H. (2008): Dynamique environnementale en zones sahélienne et soudanienne de l'Afrique de l'Ouest: Analyse des modifications et évaluation de la dégradation du couvert végétal. - Thèse de doctorat; Université de Liège, 153p.

[20] Igue, A. M. (2000): The use of a soil and terrain database for land evaluation procedures: Case study of Central Benin. - Thèse, Université de Hohenheim, Allemagne, 235p.

[21] INSAE_Benin (2014): Densite de la population. - National Institute of Statistics and Economic Analysis.

[22] Issiaka, N. T., Arouna, O., Imorou, I. T. (2016): Cartographie De La Dynamique SpatioTemporelle Des Parcours Naturels des Troupeaux Transhumants Dans Les Communes De Banikoara Et De Karimama Au Bénin (Afrique De L’ouest). - European Scientific Journal 12(32): 251-268.

[23] Kaimowitz, D., Angelsen, A. (1998): Economic, models of tropical deforestation: A review. - Bogor: Center for International Forestry Research. 
[24] Kpédénou, K. D., Boukpèssi, T., Tanzidani, T., Tchamie, K. (2016): Quantification of land use changes in Yoto Prefecture (Southeast Togo) using Landsat satellite imagery. Biogeographical Research and Environmental Studies Laboratory (University of Lomé), Environmental Science Journal, pp. 137-156.

[25] Kumar, M., Shaikh, V. R. (2013): Site suitability analysis for urban development using GIS based multicriteria evaluation technique. - J Indian Soc Remote Sens 41(2): 417-424.

[26] Lambin, E. F., Baulies, X., Bockstael, N., Fischer, G., Krug, T., Leemans, R., Vogel, C. (1999): Land-use and land-cover change (LUCC) - Implementation strategy (IGBP Report 48/IHDP Report 10). - A core project of the International Geosphere-Biosphere Programme and the International Human Dimensions Programme on Global Environmental Change. Stockholm: IGBP Secretariat \& Bonn, Switzerland: IHDP Secretariat.

[27] Lambin, E. F., Turner, B. L., Geist, H. J., Agbola, S. B., Angelsen, A., Bruce, J. W., Coomes, O. (2001): The causes of land-use and land-cover change: moving beyond the myths. Global environmental change-human and policy dimensions. - Glob Environ Change 11(4): 261-269.

[28] Lambin, E. F., Meyfroidt, P. (2010): Land use transitions: socio-ecological feedback versus socio-economic change. - Land Use Policy 27(2): 108-118.

[29] Lambin, E. F., Meyfroidt, P. (2011): Global land use change, economic globalization, and the looming land scarcity. - Proc Natl Acad Sci USA 108(9): 3465-3472.

[30] Li, X., Zhou, W., Ouyang, Z. (2013): Forty years of urban expansion in Beijing: what is the relative importance of physical, socioeconomic, and neighborhood factors? - Appl Geogr 38(1): 1-10.

[31] Lu, X., Sasaki, K. (2008): Urbanization process and land use policy. - Ann Reg Sci 42: 769-786.

[32] Mama, A., Sinsin, B., De Cannière, C., Bogaert, J. (2013): Anthropisation et dynamique des paysages en zone soudanienne au nord du Bénin. - Tropicultura 31(1): 78-88.

[33] Mather, A. S., Needle, C. L. (2000): The relationships of population and forest trends. The Geographical Journal 166(1): 2-13.

[34] Meyer, W. B., Turner II, B. L. (1992): Human population growth and global land-use/landcover change. - Annual Review of Ecology and Systematics 23: 39-61.

[35] Meyfroidt, P., Lambin, E. F., Erb, K. H., Hertel, T. W. (2013): Globalization of land use: distant drivers of land change and geographic displacement of land use. - Curr Opin Environ Sustain 14: 78.

[36] Mishra, V. N., Rai, P. K. (2016): A remote sensing aided multi-layer perceptron- Markov chain analysis for land use and land cover change prediction in Patna district (Bihar), India. - Arabian J Geosci 9(4): 249.

[37] Mishra, V. N., Rai, P. K., Prasad, R., Punia, M., Nistor, M. M. (2018): Prediction of spatiotemporal land use/land cover dynamics in rapidly developing Varanasi district of Uttar Pradesh, India using Geospatial approach: a comparison of hybrid models. - Appl Geomat 10(3): 257-276.

[38] Moghadam, H. S., Helbich, M. (2013): Spatiotemporal urbanization processes in the megacity of Mumbai, India: Markov chains-cellular automata urban growth model. - Appl Geogr 40: 140-149.

[39] Ngo Makak, R., Sanou, P., Toure, I., Tchindjang, M., Makak, J. S. (2018): Analyse diachronique de l'occupation des terres pour la conception d'une base de données géoréférencées de suivi des dynamiques territoriales dans la commune rurale de Koumbia au Burkina Faso. - Revue Scientifique et Technique Forêt et Environnement Du Bassin Du Congo 10: 23-35.

[40] Ojima, D. S., Galvin, K. A., Turner II, B. L. (1994): The global impact of land-use change. - Bioscience 44(5): 300-304. 
[41] Oladoye, A. O., Aduradola, A. M., Adedire, M. O., Agboola, D. A. (2014): Composition and stand structure of a regenerating tropical rainforest ecosystem in South-western Nigeria. - International Journal of Biodiversity and Conservation 6(11): 764-776.

[42] Oloukoi, J., Mama, V. J., Agbo, F. B. (2006): Modeling the dynamics of land use in the Hills department in Benin. - Remote sensing 6(4): 305-323.

[43] Oloukoi, J. (2012): Usefulness of remote sensing and geographic information systems in the study of the spatial dynamics of land use in central Benin. - Doctoral thesis in Geography, UAC, Benin, 304p.

[44] Ousséni, A., Gervais, E. C., Dramane, I. (2016): Dynamique de l'occupation des terres et état de la flore et de la végétation dans le bassin supérieur de l'Alibori au Benin. - Journal of Applied Biosciences 108: 10543-10552.

[45] Pacheco, P., Poccard-Chapuis, R. (2012): The complex evolution of cattle ranching development amid market integration and policy shifts in the Brazilian Amazon. - Annals of the Association of American Geographers 102(6): 1366-1390.

[46] Pfaff, A., Robalino, J., Walker, R., Reis, E., Aldrich, S., Caldas, M., Kirby, K. (2007): Road investments, spatial spillovers \& deforestation in the Brazilian Amazon. - Journal of Regional Science 47(1): 109-123.

[47] Schaldach, R., Alcamo, J., Heistermann, M. (2006): The multi-scale land use change model landshift: a scenario analysis of land use change and environmental consequences in Africa. - In: $3^{\text {rd }}$ International Congress on Environmental Modelling and Software, Burlington, Vermont, USA.

[48] Schumann, K., Wittig, R., Thiombiano, A., Becker, U., Hahn, K. (2012): Uses, management, and population status of the baobab in eastern Burkina Faso. - Agrofor Syst 85(2): 263-278.

[49] Singh, A. (1989): Review article: Digital change detection techniques using remotelysensed data. - International Journal of Remote Sensing 10(6): 989-1003.

[50] Srivastava, P. K., Singh, S. K., Gupta, M., Thakur, J. K., Mukherjee, S. (2013): Modeling Impact of Land Use Change Trajectories on Groundwater Quality Using Remote Sensing and GIS. - Environ Eng Manag J. 12(12): 2343-55.

[51] Thapa, R. B., Murayama, Y. (2009): Examining spatiotemporal urbanization patterns in Kathmandu valley, Nepal: remote sensing and spatial metrics approaches. - Remote Sens 1: 534-556.

[52] Thapa, R. B., Murayama, Y. (2010): Drivers of urban growth in the Kathmandu valley, Nepal: examining the efficacy of the analytic hierarchy process. - Appl Geogr 30(1): 7083.

[53] Thomson, G. (2007): Benin political geography. - http://www.encyc loped ia.com/place s/afric a/benin -polit ical-geogr aphy/benin. Accessed 8 Feb 2018.

[54] Turner II., B. L. (2001): Land-use and land-cover change: advances in 1.5 decades of sustained international research. - Am J Agr Econ 10(4): 269-272.

[55] United Nations (2017): Benin population (2017-12-21). - http://world popul ation revie w.com/count ries/benin -popul ation. Accessed 05 Feb 2018.

[56] Vadrevu, K. P. (2013): Introduction to Remote Sensing. - In: Campbell, J. B., Wynne, R. H. (eds.) The Photogrammetric Record. Fifth ed., Guilford Press, New York.

[57] Van Asselen, S., Verburg, P. H. (2013): Land cover change or land-use intensification: simulating land system change with a global scale land change model. - Glob Change Biol 19(12): 3648-3667.

[58] Verburg, P. H., van de Steeg, J., Veldkamp, A., Willemen, L. (2009): From land cover change to land function dynamics: a major challenge to improve land characterization. $-\mathbf{J}$ Environ Manag 90(3): 1327-35. 